Portland State University

PDXScholar

\title{
Claude V. Palisca as Music Educator: The Yale Seminar on Music Education and the Norton Anthology of Western Music
}

Jelena Dj. Simonović Schiff

Portland State University

Jere T. Humphreys

Arizona State University

Follow this and additional works at: https://pdxscholar.library.pdx.edu/music_fac

Part of the Music Education Commons, and the Musicology Commons

Let us know how access to this document benefits you.

\section{Citation Details}

Simonović Schiff, Jelena Dj. and Humphreys, Jere T., "Claude V. Palisca as Music Educator: The Yale Seminar on Music Education and the Norton Anthology of Western Music" (2020). School of Music + Theater Faculty Publications and Presentations. 7.

https://pdxscholar.library.pdx.edu/music_fac/7

This Post-Print is brought to you for free and open access. It has been accepted for inclusion in School of Music + Theater Faculty Publications and Presentations by an authorized administrator of PDXScholar. Please contact us if we can make this document more accessible: pdxscholar@pdx.edu. 


\title{
Claude V. Palisca as Music Educator: The Yale Seminar on Music Education and the Norton Anthology of Western Music
}

Journal of Historical Research in Music Education

(C) The Author(s) 2019 Article reuse guidelines: sagepub.com/journals-permissions DOI: I0.II77/I5366006/9836094 journals.sagepub.com/home/jhr

\section{Jelena Dj. Simonović Schiff' and Jere T. Humphreys ${ }^{2}$}

\begin{abstract}
Claude V. Palisca (192I-200I) was a prominent American musicologist and music educator. He authored books and articles about Renaissance and Baroque music theory and developments in musicology, but is most widely known as the founder and first editor of the Norton Anthology of Western Music (NAWM) and coauthor of A History of Western Music, the two music history textbooks that are still in use in classrooms worldwide. In this article, we trace Palisca's first idea of the NAWM's structure, content, and purpose through his writings and activities between the 1950s and late 1970s. The central part among Palisca's activities in music education belongs to his organization of the Yale Seminar on Music Education, his seminar report, and the listening curriculum designed to instill more balance between performance and academic study in largely performance-oriented public school music programs. In his listening curriculum, Palisca argued for emphasis on understanding music through listening within the historical and theoretical context of the music work, an approach he would later pursue in the NAWM. Palisca hinted that a similar teaching "package" is needed for the undergraduate level, thus identifying the listening curriculum from his Yale Seminar report as the first glimmer of the future NAWM.
\end{abstract}

\section{Keywords}

Claude Palisca, Yale Seminar on Music Education, report, listening curriculum, music history pedagogy, Norton Anthology of Western Music, musical taste, highbrow

\footnotetext{
'Portland State University, Portland, OR, USA

${ }^{2}$ Arizona State University, Phoenix, AZ, USA

Corresponding Author:

Jere T. Humphreys, Arizona State University, I523 E. Hazel Dr., Phoenix, AZ 85042, USA.

Email: Jere.Humphreys@asu.edu
} 
Claude V. Palisca (1921-2001) was one of the most prolific and prominent musicologists of his time. ${ }^{1}$ He was born in what is now Croatia and took his university degrees at Queens College (New York) and Harvard University. He was on the faculty at the University of Illinois before becoming a professor of music history at Yale University, a position he held for the remainder of his career. His main interests encompassed late Renaissance and Baroque music theory and practice, trends and developments in musicology, and relationships between musicology and music education. ${ }^{2}$

Palisca's scholarship in musicology and his views on music education were integrated in a series of university textbook editions of A History of Western Music (HWM) and the Norton Anthology of Western Music (NAWM), two works that contributed significantly to his scholarly reputation. He coauthored the $H W M$ with Donald J. Grout, starting with the third edition. Some of Palisca's beliefs about music education are represented in the $N A W M$, for which he was the sole editor for the first four editions. Indeed, Palisca's work in musicology notwithstanding, his "interest in music as an intellectual discipline no doubt both influenced and was influenced by his interest in teaching. He once said that he was really only interested in things that had some pedagogical dimension."3

The topic of this article-connections between the Yale Seminar and Norton Anthology of Western Music - emerged as one of the findings in the primary author's doctoral dissertation, which was focused on the NAWM content changes through six editions (1980-2009). ${ }^{4}$ The article is shaped and expanded from the dissertation subchapters on Palisca's and Burkholder's contributions to the NAWM and their respective educational philosophies. The research method used relied on the one used in the dissertation: primarily a content analysis of the thirteen volumes (five two-volume editions and a three-volume sixth edition) of the $N A W M$ that constitute primary sources. ${ }^{5}$ Concurrent with the analysis of $N A W M$ content transformation, an exhaustive examination of Palisca's entire writing oeuvre, especially in the field of music

${ }^{1}$ This article is based on a portion of the principal author's doctoral dissertation, Jelena Dj. Simonović Schiff, "Music History Pedagogy: Content Analysis of Six Editions of the Norton Anthology of Western Music (1980-2009)" (DMA diss., Boston University, 2012), in ProQuest Dissertations and Theses.

2Paula Morgan, "Palisca, Claude V(ictor)," Grove Music Online (accessed December 3, 2017).

${ }^{3}$ Thomas J. Mathiesen, "Foreword" to Music and Ideas in the Sixteenth and Seventeenth Centuries by Claude V. Palisca (Urbana: University of Illinois Press, 2006): viii.

${ }^{4}$ Simonović Schiff, "Music History Pedagogy."

${ }^{5}$ The method involved the following steps: (1) identification of categories of changes that occurred in every edition after the first; (2) recording all entries for all composers in the first edition, including the title of each work, name of composer, and title of the chapter in which the work appeared, adding new composers and new works for every subsequent edition, and tracking all changes to the titles, excerpts, composers' names, and chapter titles in every subsequent edition; (3) developing levels of representation for each individual composer and each 
education, as well as writings of other authors related to Palisca, including those about his music education activities, ${ }^{6}$ as secondary sources, revealed that $N A W M$ content appeared as a logical result of its author's pedagogical views.

The purpose of this research was to expound on a relationship between Palisca's work on the Yale Seminar and-what seemed as a consequent-creation of the Anthology, by chronologically tracing Palisca's thoughts and actions manifested through his writings, while describing the surrounding circumstances at the time. This article hinges on both music history pedagogy and music education, and its authors' intention is to show how Palisca treated the two disciplines similarly, bridging ideas from public school to college level, and stemming concepts from the Yale Seminar into the Anthology. The present research may contribute to the account of American music history pedagogy during the second half of the twentieth century.

\section{Palisca's Work in the Field of Music Education}

Palisca's interest in music education manifested itself in articles and reviews starting while he was in his thirties. It continued until the publication of his final article on music education in 1979. In between, he published (1) book reviews, (2) works about the 1963 Yale Seminar on Music Education, (3) articles on other education-related topics, and (4) textbooks.

Early in this three-decade period, Palisca reviewed two textbooks designed for undergraduate courses in music history and appreciation: The Enjoyment of Music by Joseph Machlis and An Introduction to Music by David D. Boyden. While he initially found that "[b]oth authors have produced readable, trustworthy books," in the greater part of the review he evaluated "how they fare in the classroom." $\mathrm{He}$ opined that "the

individual work; (4) computing composers' representation levels with composition representation levels; (5) assembling the list of most represented composers and works from data; (6) determining how changes in representation of individual composers and works influenced all observed categories of changes; and (7) interpreting $N A W M$ transformation in the context of general trends in the field with possible implications for music history pedagogy.

${ }^{6}$ The literature about Palisca's professional activities consists of works written by him and those written about him. Works written by Palisca can be classified as (1) books (authored, coauthored, edited, coedited, translated, and cotranslated); (2) textbooks (edited and coedited); (3) scholarly journal and encyclopedia articles; (4) reviews of works (books and recordings) by other authors and performers; and (4) educational reports and articles related to music education. The body of literature written about Palisca consists of (1) reviews of his books (authored, coauthored, edited, coedited, and translated) and journal articles; (2) reviews of his educational reports; (3) works dedicated to him; (4) reviews of the works dedicated to Palisca; and (5) obituaries. For more on writings by and about Claude V. Palisca see Simonović Schiff, "Music History Pedagogy," 50-106.

${ }^{7}$ Claude V. Palisca, review of The Enjoyment of Music: An Introduction to Perceptive Listening, by Joseph Machlis; The Enjoyment of Music, shorter edition, by Joseph Machlis; and 
most disturbing weakness in both of these books . . . is the little attention paid to the student's growth," and that they tend to force the repertory upon the instructor. ${ }^{8}$

These remarks foreshadowed Palisca's design for the NAWM more than twenty years hence. The inclusion of commentaries with analytical explanations for compositions appearing in the Anthology served to engage students in analysis of the pieces. Ironically, however, in imposing his choices, Palisca restricted the repertory for the course instructors and students who were to use the Anthology.

In addition to his review of these two textbooks, during that early portion of his career Palisca reviewed a third book, a book related to education but not directly to music education, titled One Great Society: Humane Learning in the United States by Howard Mumford Jones. ${ }^{9}$ In this book Jones articulated an urgent need for support and preservation of the humanities. Palisca agreed completely on the need for such support, and both the author and reviewer articulated highly conservative positions on what constituted "humane" (high) arts versus the popular arts. Both writers deemed the popular arts unworthy of special support and preservation. Palisca wrote:

\begin{abstract}
Without the record of human life at its most intense, noble, heroic, and diverse, of which the humanities are custodians, we would soon be reduced to the level of brutes. The fine arts occupy an important part of this heritage, but we are urged to distinguish the "humane" arts from the booming popular arts dedicated to amusement and entertainment. "The important truth, which American education has not yet quite learned," Jones warns, "is not to mistake the function of the one for the function of the other, not to expect from the relaxation sold by the entertainment industry the intellectual challenge of the fine arts and of philosophy. . . . Great art . . has no obligation to entertain. Its duty lies in the direction of illumination, depth, and growth." Our artistic organizations — and this goes for public school music - can justify their demands for public and private support in the present crisis only if they embrace this "humane" aspiration. ${ }^{10}$
\end{abstract}

With these words, Palisca presaged the approach he would take with the NAWM. He remained faithful to his conviction in distinguishing the "humane" arts from "the booming popular arts dedicated to amusement and entertainment" by limiting musical

\footnotetext{
An Introduction to Music, by David D. Boyden, Journal of the American Musicological Society 10 (Autumn 1957): 201-3 (quoted material from p. 201). The first edition of The Enjoyment of Music: An Introduction to Perceptive Listening and the shorter edition of The Enjoyment of Music were published in New York by W. W. Norton \& Company, Inc., in 1955 and 1957, respectively. Boyden's An Introduction to Music was published in New York by Alfred A. Knopf in 1956.

${ }^{8}$ Ibid., 202.

${ }^{9}$ Howard Mumford Jones, One Great Society: Humane Learning in the United States (New York: Harcourt, Brace \& Co., 1959).

${ }^{10}$ Claude V. Palisca, review of One Great Society: Humane Learning in the United States, by Howard Mumford Jones, Notes, Second Series 17, no. 1 (December 1959): 39-40 (quoted material from p. 39).
} 
content for the NAWM strictly to Western art music. Palisca wrote those words in 1959, only four years after Gilbert Chase had become "the first notable historian of American music to treat popular music seriously." 11 At that time, with rock and roll emerging, American popular music was a burgeoning phenomenon. Nevertheless, Palisca's views remained consonant with those of other musicologists of his generation. It was not until the fifth $N A W M$ edition in 2006 that his coeditor and eventual successor, J. Peter Burkholder, introduced jazz to the Anthology, the first music from outside the Western art music tradition to gain entry into the $N A W M .^{12}$

\section{The Yale Seminar}

The Yale Seminar on Music Education was one of a succession of school subjectmatter seminars and symposia inspired by the Woods Hole Conference held at Woods Hole, Massachusetts, in September 1959. This and other conferences were organized in response to claims that the alleged poor quality of American schools in comparison to those of the Soviet Union, especially in mathematics and science, had contributed significantly to the United States' allegedly falling behind in the "space race" following the successful launch of the Soviet space satellite Sputnik in October 1957. Among other things, concerns over Sputnik led to much greater federal involvement in education, which previously had been limited mainly to data-gathering.

The administration of President John F. Kennedy played a major role in planning and funding the Yale Seminar. According to Steele, the symposium proposers assumed that the Kennedy administration would look favorably on a prestigious institution like Yale University, where Palisca held a faculty position. ${ }^{13}$ Palisca followed up on his early articles and reviews on music education by planning and administering the seminar, which took place on June 17-28, 1963, at Yale University in New Haven, Connecticut. The Office of Education of the United States Department of Health, Education and Welfare sponsored the seminar through a grant under the Cooperative Research Program, established in 1954 by an Act of Congress, PL 531, which encourages research in educational processes. ${ }^{14}$

\footnotetext{
${ }^{11}$ Jere T. Humphreys, "Popular Music in the American Schools: What the Past Tells Us about the Present and the Future," in Bridging the Gap: Popular Music and Music Education, ed. Carlos Xavier Rodriguez (Reston, VA: MENC: The National Association for Music Education, 2004), 91. Chase's survey of American music history appeared as Gilbert Chase, America's Music: From the Pilgrims to the Present (New York: McGraw-Hill, 1955).

${ }^{12}$ J. Peter Burkholder and Claude V. Palisca, eds., Norton Anthology of Western Music, 5th ed. (New York: Norton, 2006).

${ }^{13}$ Daniel L. Steele, "Background of the Yale Seminar on Music Education," Bulletin of Historical Research in Music Education 13, no. 2 (July 1992): 67-83 (paraphrased material from p. 76).

${ }^{14}$ Grant Beglarian, review of Music in Our Schools: A Search for Improvement, Report of the Yale Seminar on Music Education, prepared by Claude V. Palisca, Journal of Music Theory 9 (Spring 1965): 187-89 (material cited from p. 187).
} 
The orientations of the host institution and of Palisca himself were reflected in the composition of the group of seminar participants, which included eleven music theorists and composers, five public and private school music teachers, four conductors, three musicologists, three university music education administrators, two performers, one public school administrator, one "educationist," and one music critic - a total of thirty-one participants, plus an additional thirteen observers. The geographical representation was highly skewed toward the Northeast region. ${ }^{15}$ The representatives were also heavily skewed toward university professors with little or no experience in public school music education.

In addition to organizing and administering the Yale Seminar, Palisca wrote the final report, titled Music in Our Schools: A Search for Improvement, published in 1964 by the U.S. Department of Health, Education and Welfare, Office of Education. ${ }^{16}$ The report consists of ten chapters preceded by preliminary pages and followed by an appendix containing information about the seminar participants and observers. The content of the report generally follows the seminar agenda expressed in six points:

The work of the Seminar was divided between plenary meetings to hear and discuss prepared papers and sectional meetings concentrating on six areas: (1) the teaching of music reading through making and writing music; (2) the widening of the music repertory of performing groups in light of recent historical and ethnological research; (3) the development of musical understanding through a study of music as a literature; (4) the utilization of composers and performers in residence; (5) the development of new educational media, such as films, tapes, and programmed instruction; (6) development of courses, resources, and activities for students who are more advanced musically than their contemporaries. ${ }^{17}$

Palisca justified the need for the seminar in two main aspects: "It was probably the first time in recent history that such a cross section of professional interests in music was achieved in an extended conference on music teaching"; and "the lack of communication between the realms of music education and professional activity implied in this realization." 18 In the recommendations portion of the report, Palisca stated that

the best possible performance should always be expected, and no sloppiness of thinking or action tolerated; the repertory "should be more representative than it is, not only of our

\footnotetext{
${ }^{15}$ Charles Leonhard, "Was Yale Seminar Worthwhile?," Bulletin of the Council for Research in Music Education, no. 60, special issue The Yale Seminar on Music Education (Fall 1979): 61-64 (material cited from p. 61).

${ }^{16}$ Claude V. Palisca, Music in Our Schools: A Search for Improvement, "Report of the Yale Seminar on Music Education," Bulletin no. 28 (Washington, DC: US Dept. of Health, Education and Welfare, Office of Education, OE 33033, 1964).

${ }^{17}$ [n.a.], "Seminar on Music Education," Music Educators Journal 50, no. 1 (September-October 1963): 86-87 (material cited from p. 86).

${ }^{18}$ Palisca, Music in Our Schools, 1.
} 
Western musical heritage at its best, but also of jazz and folk music, and of non-Western culture"; every high school should offer courses in music literature with a limited number of representative works studied in depth; "activities such as the marching band ... are not to be discouraged since they can lead students to greater participation, but they should not be ends in themselves"; theory and literature courses "beyond those offered to the average student should be available to those sufficiently advanced musically"; a program should be fostered to bring musicians, composers, and scholars to schools; and that training in music should be given to teachers who are not musicians, training in teaching to musicians who are not teachers, and retraining in music to teachers now teaching music. ${ }^{19}$

\section{Reflections on the Seminar and Palisca's Report in 1965}

In 1965, several authors wrote articles in response to Palisca's report. Some agreed with his conclusions, but others criticized it in various ways. Seminar non-participant Grant Beglarian wrote that "because the general tone of the Seminar Report is critical of the many weaknesses in public school music programs, the uninitiated reader can be easily misled into thinking that nothing good exists in the program."20 Music education professor and seminar nonparticipant Paul Lehman commented that the suggestions in Palisca's report concerned some basic activities that had been practiced by teachers for many years, often with success, and remarked that "no sooner had the report of the seminar been published than there arose a series of anguished protests from large segments of the nation's music educators . . . based . . . upon the inherent allegation that in many respects music education was failing to accomplish all that it should." 21

In the fall 1965 issue of the Bulletin of the Council for Research in Music Education, three authors reflected on the seminar and report, and also proposed solutions according to Palisca's guidelines set forth in the report. Seminar participant Joseph Turner, representative of the Executive Office of the President, Office of Science and Technology, wrote that the "Yale Seminar was productive in a number of ways."22 Nonparticipant Kenneth Wendrich, an assistant professor of music education at Yale University, stated that educational practices in American schools place stronger emphasis on performance than on listening. He proposed a curriculum in music listening $^{23}$ that would meet "not only the immediate technical needs of the teacher, but also rigorous academic standards of scholarship." ${ }^{24}$ Seminar participant Ronald B. Thomas,

\footnotetext{
${ }^{19}$ Ibid., 53-56.
}

${ }^{20}$ Beglarian, review of Music in Our Schools, 187.

${ }^{21}$ Paul R. Lehman, review of Music in Our Schools: A Search for Improvement, Notes, Second Series 22, no. 1 (Autumn 1965): 728-30 (material cited from p. 728).

22Joseph Turner, "Innovation and Experiment in Music Education," Bulletin of the Council for Research in Music Education 6 (Fall 1965): 1-8 (material cited from p. 1).

${ }^{23}$ Wendrich became director for the listening curriculum project (see footnote 24, p. 11).

${ }^{24}$ Kenneth L. Wendrich, "An Approach to Musical Understanding to Secondary Students," Bulletin of the Council for Research in Music Education, no. 6 (Fall 1965): 9-11 (material cited from p. 9). 
a teacher in the Nanuet, New York, Public Schools who moved to Manhattanville College of the Sacred Heart in Purchase, New York, ${ }^{25}$ proposed a study of selected schools with innovative music programs. ${ }^{26}$ These early reviews of Palisca's report and proposals based on the report recommendations demonstrate the resentment, but also interest and optimism, in certain music circles about the role of the seminar and its findings as set forth in the seminar report.

\section{Palisca's Listening Curriculum}

In 1964, Palisca, Luther Noss, and Wendrich, all of Yale (Noss as dean of Yale School of Music), proposed to the US Office of Education a project to develop a listening curriculum. The proposal was accepted and a contract was signed in 1965. The approved plan included testing the curriculum in selected public schools for three years. In addition to Palisca and Wendrich, six other music professionals joined the research and the development of the curriculum. "At the basis ... of the curriculum has been the philosophy about musical explanation. . . . In this sense our goal is not 'appreciation.' Rather, we searched for ways to reach an understanding of music, assuming that with understanding comes enjoyment, and even if it does not, the knowledge gained is valuable in itself." ${ }^{27}$ The proposed listening curriculum was composed of nine units, each devoted to one or more selected musical works. Units were organized by genre (as opposed to chronologically) and each unit included approximately 20 lessons. ${ }^{28}$

The unifying idea behind the Yale Seminar report recommendations and the listening curriculum proposed by the group of authors led by Palisca was to introduce more

\footnotetext{
${ }^{25}$ [n.a.], "Seminar on Music Education," 87.

${ }^{26}$ Ronald B. Thomas, "A Study of New Concepts, Procedures, and Achievements in Music Learning as Developed in Selected Music Education Programs," Bulletin of the Council for Research in Music Education, no. 6 (Fall 1965): 25-26. By this time, Thomas was already developing his own federally funded experimental music curriculum project. See Kyung-Suk Moon, "Historical Perspectives on the Manhattanville Music Curriculum Program: 1965-1972" (DMA diss., Arizona State University, 2004); and Kyung-Suk Moon and Jere T. Humphreys, "The Manhattanville Music Curriculum Program: 1966-1970," Journal of Historical Research in Music Education 31, no. 2 (April 2010): 75-98.

${ }^{27}$ Claude V. Palisca, "A Curriculum for Understanding Music through Discovery and Discussion: The Yale Music Curriculum Project," College Music Symposium 9 (Fall 1969): 36-47 (material cited from pp. 39-40).

${ }^{28}$ (1) Music for the Dance, Stravinsky Petrushka, by Palisca; (2) Music for the Keyboard, Schubert "Impromptu" and Chopin "Ballade" in g-minor, by Plantinga; (3) Chamber Music, Haydn, "String Quartet" op. 76, no. 3, by Palisca; (4) The Symphony, Beethoven Eroica, by Palisca and La Rue; (5) The Concerto, Bach Brandenburg no. 5 and Brahms "Violin Concerto," by Palisca; (6) The Opera, Verdi Otello, by Yellin; (7) The Oratorio, Handel Saul, by Palisca; (8) Program Music, a survey from Vivaldi to Schoenberg, by Plantinga; (9) American Music, jazz, Ives, Schuller, James Drew, by Drew (see Palisca, "A Curriculum for Understanding Music," pp. 37-38).
} 
balance into predominantly performance-oriented public school music programs. Stating that the "[h]igh school music programs are overwhelmingly addressed to performers - singers and players of band orchestra instruments," ${ }^{29}$ Palisca argued for emphasis on understanding music through listening within the historical and theoretical context of the music work. This was the approach he would later pursue in the Norton Anthology of Western Music. The belief that every high school should offer courses in music literature with a number of representative works studied in depth; that theory and literature courses should be available to those sufficiently advanced musically; and that music programs should embrace musicians, composers, and scholars into curriculum ${ }^{30}$ underlay Palisca's conviction that music education at every level should offer programs balanced between academic disciplines and performing.

In the listening curriculum, Palisca presented suggestions for analysis and discussion of the incorporated pieces in a fashion that would later characterize the commentaries introduced in the third edition of the NAWM. At the time of the testing of the listening curriculum in public schools music classrooms, Palisca hinted at a similar teaching "package" for the undergraduate level: "As the project developed, it became obvious that no materials of parallel scope and quality were available for college introductory courses in music. We decided to test an adaptation of the curriculum for college classes. . . . So far the results have been encouraging." ${ }^{31}$ The creation of the listening curriculum as recommended by Palisca in the Yale Seminar report in the mid-1960s represented the first glimmer of the future Norton Anthology of Western Music.

\section{Reflections on the Seminar and Palisca's Report in 1979}

Fifteen years after the Yale Seminar, a special issue of the Bulletin of the Council for Research in Music Education was devoted to the event and its effects on music education in the United States. Seventeen authors contributed to the issue. Among them were ten original seminar participants and one observer. Seven authors, including Palisca, expressed positive sentiments toward the seminar, three were neutral, and seven expressed mostly negative opinions. As for outcomes, four former participants reported positive outcomes from the seminar during the intervening fifteen years, three were neutral, and three participants and one observer reported unfavorable outcomes. In what proved to be his final education-related article, Palisca wrote the "Prefatory Remarks" in a somewhat resigned tone:

Some of the commentators who are involved in music education professionally also imply that they would have been better qualified to participate in that dialogue than those

\footnotetext{
${ }^{29}$ Palisca, “A Curriculum for Understanding Music,” 36.

${ }^{30}$ Palisca, Music in Our Schools, 53-56.

${ }^{31}$ Palisca, “A Curriculum for Understanding Music," 42.
} 
actually invited. That is debatable. ... The statements gathered here do not contain much that surprises me, unless it is that they credit the Seminar with greater influence on music education than I have had the opportunity to observe. ${ }^{32}$

Certain perceived strengths and weaknesses of the seminar and report can be gleaned from the writings of the seventeen reviews in this fifteenth anniversary issue (and from other articles published between 1964 and 1979). In general, authors expressed positive sentiments about the recommendations to include jazz and nonWestern music in the curriculum, and for the recommendations for ample funding opportunities for music education research projects. Positive reviews of the seminar outcomes came from participants Howard L. Boatwright, Allen P. Britton, Lionel Nowak, and Claude V. Palisca and from nonparticipants/observers Robert Y. Hare, Charles Leonhard, and Robert J. Werner.

For seminar participant Boatwright, a music theorist and composer at Yale at the time of the seminar and at Syracuse at the time of the article referenced here, ${ }^{33}$ positive outcomes were the recommendations to admit non-Western music and the notion of integrating music theory with music history, literature, and performance for a more comprehensive music curriculum. ${ }^{34}$ Similarly, Allen Britton, a participant representing music education and music administration from the University of Michigan, noted that in the years following the seminar recommendations, jazz became "much more studied" in schools than it had been in 1963, and that "despite disappointments, the Yale Seminar was one of the good things. It inspired reflective thinking, and it continues to inspire such thinking." 35 Lionel Nowak of Bennington College pointed out that as a result of the seminar, there is "less isolation among educators, composers, performers, and musicologists." 36

Among nonparticipants, Robert Hare (Ohio State University) and Charles Leonhard (University of Illinois) noted that the seminar report had a positive impact on further funding of research projects. Robert Werner (University of Arizona) thought that it provided a strong statement that called for reform. ${ }^{37}$

\footnotetext{
${ }^{32}$ Claude V. Palisca, "Prefatory Remarks," Bulletin of the Council for Research in Music Education, no. 60, special issue The Yale Seminar on Music Education (Fall 1979): 1-4 (material quoted from p. 1).

${ }^{33}$ [n.a.], "Seminar on Music Education," 86-87.

${ }^{34}$ Howard [L.] Boatwright, "Reflections," Bulletin of the Council for Research in Music Education, no. 60, special issue The Yale Seminar on Music Education (Fall 1979): 34.

${ }^{35}$ Allen P. Britton, "In Response," Bulletin of the Council for Research in Music Education, no. 60, special issue, The Yale Seminar on Music Education (Fall 1979): 59-60 (quotation from p. $60)$.

${ }^{36}$ Lionel Nowak, "Yale Seminar Review: 15 Years Later," Bulletin of the Council for Research in Music Education, no. 60, special issue The Yale Seminar on Music Education (Fall 1979): 17-21 (citation from p. 17).

${ }^{37}$ Robert Y. Hare, "Yale Seminar on Music Education 1963: An Assessment 1978," Bulletin of the Council for Research in Music Education 60, special issue, The Yale Seminar on
} 
The neutral reviewers, all original participants, did not express criticism toward the seminar or its report per se, but they did not see positive influences from it either. Ronald B. Thomas (music teacher and administrator in the New York Public Schools in 1963) found that the seminar strove for "a new era in school music," but meanwhile the world had changed, leaving the schools in a worse position than they were in 1963: "Stagnancy has replaced dynamism. 'Creativity,' 'new ideas,' 'achievement' are only words, not prevalent attitudes." 38 Similarly, Gideon Waldrop (administrator at the Juilliard School) concluded that the conference was interesting and valuable, but its overall impact had been limited. ${ }^{39}$ Joseph Turner (US Office of Science and Technology) pointed to the increased centralization of school governance that followed the seminar. He suggested that the "responsibility is removed progressively from teachers to principals, to superintendents, to state and national offices of education and legislatures" and that what is needed is a "concept of school management based on local decisions and local involvement of talent." ${ }^{40}$

Unfavorable assessments of the seminar were expressed by three original seminar participants, John Carton, Marcus Raskin, and Jerrold Ross, observer Edmund A. Cykler, and three nonparticipants, Bennett Reimer, Charles Hoffer, and Robert W. John. Their principal objections concerned what was perceived as harsh language that insinuated a massive failure of public school music education and an elitist stand by mostly noneducator participants.

More specifically, participant John Carton (music teacher/administrator at the Shirely Center in 1963, Peabody Conservatory in 1979) declared the conference ineffective in ending isolation among factions of musicians (i.e., educators, composers, performers, and musicologists), and stated that it had resulted in little change. ${ }^{41}$ Participant Marcus Raskin (US government Panel on Research and Development; Institute for Policy Studies in 1979) expressed his hope to move beyond "high art" to

Music Education (Fall 1979): 40-43 (material quoted from p. 40); Charles Leonhard, "Was Yale Seminar Worthwhile?" 61; and Robert J. Werner, "The Yale Seminar: From Proposals to Programs," Bulletin of the Council for Research in Music Education, no. 60, special issue, The Yale Seminar on Music Education (Fall 1979): 52-58 (material used from p. 57).

${ }^{38}$ Ronald B. Thomas, "Review of the Yale Conference: 15 Years Later," Bulletin of the Council for Research in Music Education, no. 60, special issue, The Yale Seminar on Music Education (Fall 1979): 15-16 (quotation from p. 15).

${ }^{39}$ Gideon Waldrop, “A Response," Bulletin of the Council for Research in Music Education, no. 60, special issue, The Yale Seminar on Music Education (Fall 1979): 33. Waldrop was seminar participant and an administrative officer from the Julliard School of Music (see note 14).

${ }^{40}$ Joseph Turner, "Musicians in the Schools or Standards without Standardizations," Bulletin of the Council for Research in Music Education, no. 60, special issue, The Yale Seminar on Music Education (Fall 1979): 50-51 (quoted from pp. 50-51).

${ }^{41}$ John Carton, "Interview with John Carton," Bulletin of the Council for Research in Music Education 60, special issue, The Yale Seminar on Music Education (Fall 1979): 22-24 (cited from p. 22). According to the Music Educators Journal from Fall 1963. 
include "jazz, ragtime, and folk song." 42 Jerrold Ross (a music administrator from New York University) criticized seminar members who "had . . . assumed the role of prosecutor, attacking every percept, which more successfully than not, had linked children and music since education began." 43 Seminar observer Edmund A. Cykler (University of Oregon) stated that if the purpose of the Yale Seminar was to improve the repertoire of public school music classes, it had failed. ${ }^{44}$

In his lengthy article about the Yale Seminar and report, nonparticipant Bennett Reimer (Northwestern University) expressed his belief that the seminar had failed because it had been dominated by people from outside the school music profession. He summarized that the reasons for the seminar failure were domination of people who were not in school music education, and the seminar's single-minded focus on music itself to the total exclusion of societal problems. The two other negative reviewers among nonparticipants both expressed similar criticisms, including Charles Hoffer (Indiana University) and Robert W. John (University of Georgia). ${ }^{45}$ All three of these authors were music education professors at their respective institutions.

In his dissertation-based article published in 1992, Daniel L. Steele presented a thorough history of events leading up to the Yale Seminar. Near the end of the article, Steele concluded that "the Yale Seminar on Music Education initially angered many music educators, but spurred the music education profession into action through programs of the Contemporary Music Project and the Yale inspired Tanglewood Symposium." ${ }^{46}$

Besides his works directly related to the seminar, Palisca published other articles on music education (but not immediately connected to the seminar). In a three-part article

\footnotetext{
${ }^{42}$ Marcus Raskin, "Yale from a Political Scientist's View," Bulletin of the Council for Research in Music Education, no. 60, special issue, The Yale Seminar on Music Education (Fall 1979): 31-32 (material quoted from p. 31). According to the 1963 article in Music Educators Journal. ${ }^{43}$ Jerrold Ross, "Since Yale," Bulletin of the Council for Research in Music Education, no. 60, special issue, The Yale Seminar on Music Education (Fall 1979): $44-49$ (material quoted from p. 44). ${ }^{44} \mathrm{E}$ [dmund]. A. Cykler, "In Retrospect," Bulletin of the Council for Research in Music Education, no. 60, special issue, The Yale Seminar on Music Education (Fall 1979): 35-36 (cited from p. 35).

${ }^{45}$ Bennett Reimer, "The Yale Conference: A Critical Review," Bulletin of the Council for Research in Music Education, no. 60, special issue, The Yale Seminar on Music Education (Fall 1979): 5-14 (cited from pp. 5-6); Charles R. Hoffer, "Some Thoughts on the Final Report of the Yale Seminar," Bulletin of the Council for Research in Music Education, no. 60, special issue, The Yale Seminar on Music Education (Fall 1979): 25-30 (cited from p. 28); and Robert W. John, "Yale Seminar-Fifteen Years Later," Bulletin of the Council for Research in Music Education 60, special issue, The Yale Seminar on Music Education (Fall 1979): 37-39 (cited from pp. 38-39).

${ }^{46}$ Daniel L. Steele, "Background of the Yale Seminar on Music Education," The Bulletin of Historical Research in Music Education 13 (July 1992): 67-83 (quotation from p. 83). See also Daniel Lee Steele, "An Investigation into the Background and Implications of the Yale Seminar on Music Education” (DME diss., University of Cincinnati, 1988).
} 
published in 1967, Palisca and his coauthors outlined six points for the successful preparation of graduate students. They argued that college music departments should ensure that students are well grounded in musical composition, historically oriented musical analysis, special interests within music, high artistic level of musical performance, writing articles with tight organization and clear communication, and in informal but disciplined discussion of musical problems. ${ }^{47}$

In an article published in 1971, Palisca urged American musicology and higher education to move from collection and description toward explanation, diversification, and specialization in certain multidisciplinary directions: "University departments of music should be as little alike as possible; then students would truly have a choice." 48 In the context of all of Palisca's writings, the title of his 1976 article, "The Quality of Life and the Education of the Musical Amateur," 49 invites curiosity. Palisca had always promoted the highest standards for music professionals, but here he suggested that high-level music making is too much fun to be left to professionals, and that the "training of the gifted amateur should become a high priority of our conservatories, colleges, and universities. ${ }^{\prime 50}$ In this article, Palisca clearly tried to moderate his position and conciliate his critics, in comparison to his 1964 statement that "the best possible performance should always be expected, and no sloppiness of thinking or action tolerated." ${ }^{51}$

\section{Realization of Palisca's Educational Beliefs in the NAWM}

Palisca's most substantive contributions to music education, those for which he was and remains best known, are his two textbooks. The first was the Norton Anthology of Western Music, the first edition of which came out in 1980 (J. Peter Burkholder joined in for the fifth edition in 2006, after Palisca's death). The second was A History of Western Music that Palisca coedited with Donald Jay Grout, starting with the third edition in 1980 (and they were both joined posthumously by Burkholder for the seventh edition in 2006). Altogether, Palisca solely edited the first four editions of the NAWM and coedited four editions of the HWM (3-6). He was posthumously featured as a

\footnotetext{
${ }^{47}$ Claude V. Palisca, Donald J. Grout, and Allen Winold, "Undergraduate Preparation for Graduate Study in Music," College Music Symposium 7 (Fall 1967): 91-102 (cited material from pp. 92-93).

${ }^{48}$ Claude V. Palisca, "Opportunities for Intracultural and Interdisciplinary Study," College Music Symposium 11 (Fall 1971): 100-2 (quoted material from p. 100).

${ }^{49}$ This article is omitted from the list of "Writings by Claude V. Palisca" by Elizabeth A. Keitel in Musical Humanism and Its Legacy: Essays in Honor of Claude V. Palisca, ed. Nancy Kovaleff Baker and Barbara Russano Hanning (Stuyvesant, NY: Pendragon Press, 1992). Keitel was Palisca's wife.

${ }^{50}$ Claude V. Palisca, "The Quality of Life and the Education of the Musical Amateur," College Music Symposium 16 (Spring 1976): 42-49 (quoted material from p. 44).

${ }^{51}$ Palisca, Music in Our Schools, 53.
} 
coeditor in the last three editions of both the NAWM (5-7) and $H W M(7-9)$. As a sole creator of the Anthology, Palisca was able to infuse it with the ideas he had already developed and tested while working on the seminar and listening curriculum.

One of the two driving forces behind the Yale Seminar and its report, and the resulting listening curriculum, was Palisca's determination to impose a balance between what he saw as excessive emphasis on performance in American public school music programs, as opposed to the study of music that led to knowledge and understanding. The second driving force was Palisca's devotion to European-based classical art music, as opposed to non-Western and popular music forms. He made it his educational mission to promote the knowledge and understanding of inner music mechanics gained through listening, and to promote listening in connection with historical and theoretical background of musical works of a particular style. Most of his recommendations from the report, and especially from the listening curriculum, are also reflected in the purpose, structure, and content of the Norton Anthology of Western Music.

The first $N A W M$ was published in 1980, seventeen years after the Yale Seminar (1963), eleven years after Palisca's report on the listening curriculum (1969), and in the year after the broad discourse about the seminar in the fall 1979 issue of Bulletin of the Council for Research in Music Education discussed above. In the context of Palisca's work on the realization of the seminar agenda and the creation of the listening curriculum, ${ }^{52}$ it is probable that the notion of the $N A W M$ was conceived as early as the $1960 \mathrm{~s}$.

While he utilized his report ideas about understanding music through listening in the $N A W M$, he remained faithful to his 1959 approval of Jones' position, "to distinguish the 'humane' arts from the booming popular arts dedicated to amusement and entertainment." ${ }^{\prime 53}$ Among his recommendations in the report, Palisca suggested a more inclusive repertory representative of "not only . . our Western musical heritage at its best, but also of jazz." ${ }^{4}$ It is clear from this passage that Palisca did not consider jazz part of Western music "at its best," and further, he did not even consider it part of the Western musical heritage at all. Indeed, jazz selections did not appear in the Anthology until after his death, when Burkholder came on board for the fifth edition (1980). Despite his expressed desire to broaden the repertory, in the NAWM Palisca adhered exclusively to Western art music.

Even within that tradition, Palisca's selection of composers and compositions remained conservative. He did include one woman composer (Comtessa de Dia) in the second edition (1988), but it was not until the third edition (1996) that five more women composers appeared in the NAWM. The chronology for what Palisca considered Western music was also slow to evolve. The first edition began with medieval

\footnotetext{
${ }^{52}$ Palisca, "A Curriculum for Understanding Music," 39.

${ }^{53}$ Palisca, review of One Great Society: Humane Learning in the United States, 39.

${ }^{54}$ Palisca, Music in Our Schools, 53.
} 
music, and it was not until the second edition that Ancient Greece was represented. Palisca was perhaps most conservative in his approval of modern music. Accordingly, at least forty-five significant composers are missing from the first two editions of the NAWM, most notably Pierre Boulez, John Cage, Antonin Dvořák, Francis Poulenc, Sergei Prokofiev, Giacomo Puccini, Sergei Rachmaninov, Nikolai Rimsky-Korsakov, Dmitri Shostakovich, Bedřich Smetana, Karlheinz Stockhausen, P. I. Tchaikovsky, and Edgar Varèse.

It can be said that in the $N A W M$, Palisca nurtured an antiquated approach to the shaping of musical taste in academia. According to research carried out from five years before the Yale Seminar to a couple of years before the $N A W M$ sixth edition, ${ }^{55}$ the Anthology selections lagged behind the musical preferences of the public by several decades.

\section{NAWM's Antiquated Approach to the Shaping of Musical Taste}

In his book The Social Psychology of Music published in 1958, Paul R. Farnsworth, "the originator of ... the study of music listening preference," equated listening preferences to "musical taste." ${ }^{56} \mathrm{He}$ further posited that "musical elements, their meanings, and their relations to individual behaviors can be completely understood only through social-psychological inquiry." 57 Farnsworth supplied lists of the "most frequently chosen" 58 composers by members of the Boston Symphony Orchestra and the American Musicological Society (AMS), surveyed musicologists and students, and measured the amount of space given to different composers in authoritative books and encyclopedias, on radio broadcasts and symphony orchestra programs, and in record catalogs:

If one were to condense all that Farnsworth had to say about music preference into one sentence, it might read like this: "We prefer the music that we are taught to prefer by the family, the teachers, and the peer group that socializes us from the moment of birth." 59

${ }^{55}$ Paul R. Farnsworth, The Social Psychology of Music (New York: Holt, Reinhardt and Winston, 1958); Paul R. Farnsworth, "Musicological Attitudes on Eminence," Journal of Research in Music Education 14 (Spring 1966): 41-44; Richard A. Peterson and Roger M. Kern, "Changing Highbrow Taste: From Snob to Omnivore," American Sociological Review 61, no. 5 (October 1996): 900-7; and Ercilia García-Álvarez, Tally Katz-Gerro, and Jordi López-Sintas, “Deconstructing Cultural Omnivorousness 1982-2002: Heterology in Americans' Musical Preferences," Social Forces 86, no. 2 (December 2007): 417-43.

${ }^{56}$ Albert LeBlanc, "Paul Farnsworth: Pioneer Scholar of Music Listening Preference," Bulletin of the Council for Research in Music Education, no. 149 (Spring 2001): 3-12 (quoted material from pp. 3 and 6).

57Jui-Ching Wang, “A Comparative Study of College Students' Musical Aptitude and Musical Preference in the U.S. and Taiwan" (DMA diss., Arizona State University, 2007), 6.

${ }^{58}$ Farnsworth, The Social Psychology of Music, 275.

${ }^{59}$ LeBlanc, "Paul Farnsworth," 6-7. 
Among criteria and conditioners of musical taste, Farnsworth stated that we are trained to think of music in terms of stereotypes, giving an example that even a relatively unsophisticated college student has been taught to relate the names of Mozart, Beethoven, and Schubert to certain styles of composition: "They answer not from deep conviction, but rather in accordance with their teaching. This situation is analogous to their placing Jesus, Washington, and Lincoln at the top of their lists of the most eminent men of all time." 60

Farnsworth considered training that originates in school and college teaching to be one of the principal sources of an individual's music affinities. He also found that the most performed and recorded composers are regarded as the most eminent: "Moreover, they are likely to be men whose biographical sketches occupy most space in histories of music and in general and music encyclopedias." ${ }^{1}$ In "The Musical Taste of an American Elite," 62 Farnsworth assembled two lists extracted from questionnaires sent to members of the American Musicological Society, one with the fifty most frequently chosen among the composers born since 1870, and the other with the 101 most often selected composers. ${ }^{63}$ He updated his findings in 1964, after sending 1,670 letters to the AMS members: "The ... data gathered . . clearly indicate that there exists a very considerable commonality of opinion regarding the eminence of the composers of the Western World." 64

A comparison of the NAWM 1980-2009 core repertory with what Farnsworth labeled as "the musical taste of an American elite"65 in the 1950s and 1960s reveals that almost three-quarters ( $71 \%$ and $72 \%$, respectively) of the $N A W M$ corresponded with the musical preferences expressed thirty to sixty years before the Anthology's editions were published. ${ }^{66}$ At the same time, the American elite long ago embraced composers who have still not yet appeared in the $N A W M$, or appeared for the first time in 2006 or 2009. It is here, in the complete view of $N A W M$ editions juxtaposed with the research results that precede them by several decades, that a remark by Nigel

\footnotetext{
${ }^{60}$ Farnsworth, The Social Psychology of Music, 147-48.

${ }^{61}$ Ibid., 152.

${ }^{62}$ Ibid., 275; in an Appendix to The Social Psychology of Music, also published separately in Hinrichsen's Musical Yearbook 7 (1952): 112-16.

${ }^{63}$ Ibid., 275. The questionnaires were sent in 1938, 1944, and 1951. "At the time of the last datagathering, the 375 who cooperated were given two questionnaires, one containing 225 names of composers born before 1870 and the other listing 249 born since 1870 . There were two tasks. The first was for the musicologist-respondent to check in each of the two questionnaires the ten musicians he felt had composed music most worthy to be called to the attention of his children and his lay contemporaries. As a second task, he was to consider all 474 names and, with the same criterion in mind, was to choose the top 25."

${ }^{64}$ Farnsworth, "Musicological Attitudes on Eminence," 44.

${ }^{65}$ Ibid., 42; and Farnsworth, Appendix to The Social Psychology of Music, 275.

${ }^{66}$ See Simonović Schiff, "Music History Pedagogy,” 207-12.
} 
Simeone (one of only five reviewers of $N A W M$ ) about the $H W M$ fourth and $N A W M$ second editions fully resounds: "There is something faintly disturbing about a history of music published in 1988 which takes as key 20th-century figures the same five who would have appeared in 1958." 67

\section{Toward Omnivorousness in Public Musical Taste}

More recent research studies in the area of musical preferences show that affinities toward music selections have changed during the period of NAWM's existence. National surveys conducted by Richard A. Peterson and Albert Simkus in 1982 and 1992, respectively, were based on music genres and styles rather than on individual composers. Their findings and those of Petersen and Roger Kern indicate the change in musical tastes, not only from the time of Farnsworth's work in the 1950s and 1960s but also during the ten years between the two surveys, that roughly correspond to the time of publication of the $N A W M$ first and second editions. The researchers distinguished between the "highbrow," "midbrow," and "lowbrow" status of the surveyed population in relation to their musical choices and the level of omnivorousness of their musical taste. ${ }^{68}$ Classical music and opera were considered highbrow; mood- and easy-listening music, Broadway musicals, and big band music midbrow; and country music, bluegrass, gospel, rock, and blues were considered lowbrow:

Appreciation of fine arts became a mark of high status in the late nineteenth century as part of an attempt to distinguish "highbrowed" Anglo Saxons from the new "lowbrowed" immigrants, whose popular entertainments were said to corrupt morals and thus were to be shunned.. . . . In recent years, however, many high-status persons are far from being snobs and are eclectic, even "omnivorous," in their tastes. .. . This suggests a qualitative shift in the basis for marking elite status-from snobbish exclusion to omnivorous appropriation. ${ }^{69}$

The authors defined omnivores as those open to appreciating all three levels-low-, mid- and highbrow - but not liking everything indiscriminately. Omnivorousness is in this sense "antithetical to snobbishness, which is based fundamentally on rigid rules of exclusion." "70 The cumulative research on musical taste conducted from 1982 to $2007^{71}$ was almost exactly contemporaneous with the first six editions of the NAWM

\footnotetext{
${ }^{67}$ Nigel Simeone, review of " $A$ History of Western Music by Donald J. Grout and Claude V. Palisca; and Norton Anthology of Western Music by Claude V. Palisca," The Musical Times 130 (August 1989): 477.

${ }^{68}$ Peterson and Kern, "Changing Highbrow Taste: From Snob to Omnivore," 900.

${ }^{69} \mathrm{Ibid}$.

${ }^{70}$ Ibid., 904.

${ }^{71}$ See Simonović Schiff, "Music History Pedagogy,” 202-07; see also Koen van Ejick, "Social Differentiation in Musical Taste Patterns," Social Forces 79 (March 2001): 1163-85; Phillipe
} 
(1980-2009). It revealed important indicators: that among different parameters (i.e., education, social status, age, race, gender, ${ }^{72}$ values, and generational conflict), education has lately gained more leverage; that musical preferences have broadened in the overall population, a shift most pronounced among the more educated and higher social class population; that the openness to a variety of music is evident among the younger generation; and that jazz has been upgraded from a mid- to a high-status musical "activity." In the light of this research, both Farnsworth's questionnaires, but more importantly the $N A W M$ (especially prior to the fifth edition), represented an antiquated approach, catering to seemingly vanishing highbrow tastes:

The elitist theorists of the early nineteenth century European Royal Academies of music, painting, drama, and dance argued among themselves, but they stood united in their belief that there was one standard and that all other expressions were vulgarities. ... Thus they created an aesthetic and moral environment in which highbrow snobbery flourished. ${ }^{73}$

Peterson's research from the 1980s provides strong evidence of a changing musical climate during Claude Palisca's time, changes that he ignored in his work on the NAWM. Palisca meticulously processed music of the past within the given sociocultural context in his own writings, but he failed to contextualize music that appeared during his time. He remained in the 1950s, just a step removed from solidarity with "theorists of the early nineteenth century" in regarding "relaxation sold by the entertainment industry" 74 to what they considered "vulgarities." In all his scholarship, the exhaustive knowledge in his field and beyond, his innovative undertaking in founding the $N A W M$ and its continuous improvement and updating, Palisca's rigid attitude toward anything outside the finely demarcated boundaries of-preferably European-originated or at least European-influenced-art music, seems to have impeded the potential of the Anthology to align itself with important societal shifts up to 2006 .

Coulangeon, "Social Stratification of Musical Tastes: Questioning the Cultural Legitimacy Model," Revue française de sociologie 46, Supplement: An Annual English Selection (2005): 123-54; and García-Álvarez et al., "Deconstructing Cultural Omnivorousness 1982-2002: Heterology in Americans' Musical Preferences," 417-43.

${ }^{72}$ Peterson and Kern, "Changing Highbrow Taste," 901: "In both years (1982 and 1992) highbrows, on average, have about two years more education, earn about five thousand dollars more annual family income, are about 10 years older, are more likely to be white, and are more likely to be female than are others in the sample. All of these differences are statistically significant. Neither highbrows nor others, however, are more likely to be currently married."

${ }^{73}$ Ibid., 905.

${ }^{74}$ Palisca, review of One Great Society, 39. 


\section{Conclusions}

Claude Palisca had strong pedagogical convictions, which encountered criticisms following the Yale Seminar on Music Education and the publication of his seminar report. While attempting to soften his stand and consequently exiting the public discourse about music education, his ideas were manifested in his multiedition music history textbook, the Norton Anthology of Western Music. Two of his main beliefs underlay many of his decisions and were especially important in analysis of these seminal events and products: his preference for scholarly study over performance, and his protection of the Western canon with skepticism toward modern compositions.

\section{Academic Study Versus Performance}

Palisca believed in the primacy of the academic study of music over music performance. These ideas can be traced to ancient Greece, where the study of music theory (acoustics) was valued over other types of study. There and in subsequent highly stratified European societies, academic music study was considered one of the highest forms of intellect and thus suitable for upper class (citizen) boys, whereas music performance was, according to Aristotle, done "by habit" and was thus suitable as a leisure-time activity. These ideas persisted in Europe until recent times and were transported to North America through Harvard (which did not offer a credited music course of any kind for almost three hundred years, but that is another story) and immigrants from Europe who held those beliefs.

Palisca seems not to have considered that there may have been valid reasons for what he saw as an imbalance of performance and scholarly study in extant $\mathrm{K}-12$ programs in the United States. After all, his $N A W M$ and $H W M$ were aimed toward university students and programs, not $\mathrm{K}-12$ students and programs. He failed to take into account that university music majors had time to pursue both performance and scholarly studies of music. In contrast, music was typically not a required subject above grade 6 and was taught for less than one hour per week as an elective subject that had to appeal to students. Palisca also failed to take into account the well-documented benefits, both musical and nonmusical, of participation in secondary school music performance programs, benefits that accrue to students, schools, and communities. ${ }^{75}$

Palisca was a typical classically trained European musician. His failure to distinguish between music education in American universities and $\mathrm{K}-12$ schools probably occurred because he had no formal training or experience in the latter. Moreover, very few of Yale Seminar participants and apparently none of the curriculum developers

\footnotetext{
${ }^{75}$ For more information on these issues, see Jere T. Humphreys, "United States of America: Reflections on the Development and Effectiveness of Compulsory Music Education," in The Origins and Foundations of Music Education: International Perspectives (2nd ed.), ed. Gordon Cox and Robin Stevens (London: Bloomsbury Academic, 2016), 139-53.
} 
who worked with him subsequently had public school teaching experience. Ironically, Yale University was also not known for academic programs or faculty in music education as a discipline. Thus, criticisms leveled at Palisca over the composition of the Yale Seminar participants were justified. Indeed, there could and undoubtedly should have been a better balance between academic musicians, especially those with a scholarly bent, and those with experiences and scholarly insights into $\mathrm{K}-12$ public school music education. He rejected those criticisms, but he gave no countering arguments. ${ }^{76}$

\section{Palisca's Exclusive Protection of the Western Canon}

Palisca was not well equipped to deal with public school music education and was also unprepared, or unwilling, to consider emerging trends in music. He was not a specialist in modern music of any type, or of American music of any period, having specialized in Italian art music. His views on types of music studied in the university, though not $\mathrm{K}-12$ schools, aligned with practices of his generation. Born in Europe and educated in the United States, Palisca explicitly expressed his indebtedness to the Western, exclusively European historical, scientific, literary, philosophical, artistic, and musical heritage. His published record, devoted almost entirely to ancient Greek and Renaissance-Baroque musical thought and practice, leaned, during his NAWM editorship, toward a body of music that corresponded with those periods (particularly in volume one). The very concept of the Anthology reflected Palisca's educational belief that listening with scores constituted the best way to gain knowledge about music.

Accordingly, Palisca remained loyal to European art music and protective of its status as the only Western music truly worthy of study. Through the NAWM, Palisca realized his idea of the listening curriculum replete with contextual information. His original intention, consistent with his ideas about a listening curriculum, seems to have remained unchanged during his editorship: "the philosophy about musical explanation ... [,] not "appreciation," and "an understanding of music" that does not necessarily provide enjoyment, but ensures knowledge, where "the knowledge gained is valuable in itself"; 77 an in-depth study of a limited number of chosen works within the historical context of the music studied; and knowledge as an understanding of inner workings of music gained through listening in connection with the historical and theoretical background of the musical work - represented the gist of Palisca's educational credo. What was worth understanding and gaining knowledge about was what Palisca himself understood and was knowledgeable about: the Western art music canon, confined to the works that have been approved by the passage of time and historical distance.

The works, particularly from the ancient to Baroque repertory, that Palisca studied and wrote about in his twenty book titles and numerous articles and reviews, represented the foundation of the NAWM. The closer Palisca came to contemporaneity, the more skeptical and cautious about quality he became.

\footnotetext{
${ }^{76}$ Palisca, "Prefatory Remarks," 1.

${ }^{77}$ Palisca, "A Curriculum for Understanding Music," 39-40.
} 


\section{Doubtfulness Toward Contemporaneous Composers}

Arguably, a large problem of the Anthology was its inexplicable omission of relatively recent music by both European and American composers. Major art music figures living at the time the Anthology was published were in some cases added to the NAWM after their deaths, in many instances decades after producing works that profoundly influenced developments in contemporary art music. Thus, countless university students from the 1980s through the mid-2000s did not learn about John Cage in music history courses that abided strictly by the $N A W M$. Cage was added to the Anthology only in the fifth edition, fourteen years after his death and sixty-six years after Bacchanale, his first piece for prepared piano. Similarly, these students would not have learned about Prokofiev, Boulez, or Stockhausen until the sixth NAWM edition came out in 2009. Since the Anthology was obviously intended to present Western European, and to a lesser degree American, art music, Palisca's practice of avoiding modern composers who had established themselves long before the first NAWM edition came out is a striking feature that can be seen as detrimental to the credibility of the book.

Palisca considered any form of popular music as primarily "entertainment" and irreconcilable with intellectual challenges and standards of art music. This position dubiously implies that art music was composed only from intellectual and spiritual impetus and not for entertainment, and that any work of art music included in the $N A W M$ is, by its nature, more sophisticated than any piece other than art music. By the similar exclusionary measure, some composers of art music "guilty" of the act of decanonizing were not "allowed" into the $N A W M$ until long after their works had become standard and entered the conventional repertoire. Since 2006 the $N A W M$ has become more "omnivorous," but is still encumbered by its origins.

In total, the $N A W M$ went through seven editions, two editors, and a series of changes. All of the small and large steps in the cumulative transformation fortified its content and value as a teaching tool. The appearance of the NAWM (1980) instigated the creation of an entire Norton network, ${ }^{78}$ confirming its influential place in music history pedagogy in the United States.

By 1980, the Western canon had already been challenged by emerging calls in interdisciplinary studies, feminism, the seeping of popular music into academia, and postcolonial demarginalization. At the time of its appearance, the $N A W M$ was in asynchrony with some thinking and events in the humanities and arts, and in society. By its underlying philosophy of obtaining knowledge through listening, where the gained knowledge, regardless of enjoinment, is valuable in itself; by celebrating the intrinsic values of canonized works; by strictly defining stylistic attributes of music works and circumscribing periods; and by the goal of reaching an understanding of a musical work as the final product (deemphasizing performance), Palisca's $N A W M$ reflects

\footnotetext{
${ }^{78}$ See Simonović Schiff, "Music History Pedagogy," 5-9, and 220.
} 
some of the tenets of music education as aesthetic education. These tenets, recognizable since his Yale Seminar involvement, reflected personal beliefs of the author, who had come of age during times marked by a quest for ways to label and systematize large bodies of knowledge. The lack of compromise, in that sense, was a way to contain the vastness of information, of controlling the materials, as historians sometimes strive to do, as well as to preserve what he saw as the musical "canon." The continuous presence of the $N A W M$ in higher music education despite its deficiencies, the network of other textbooks it spawned, and the issues it shares with musicology and music history pedagogy, weave the Norton Anthology of Western Music into the fabric of American music education. Because music educators also used his textbooks during the collegiate studies, further research into Palisca's role in the shaping of curricular and instructional practices in music education is recommended.

\section{Declaration of Conflicting Interests}

The author(s) declared no potential conflicts of interest with respect to the research, authorship, and/or publication of this article.

\section{Funding}

The author(s) received no financial support for the research, authorship, and/or publication of this article.

\section{Author Biographies}

Jelena Dj. Simonović Schiff is an Assistant Professor of Music History at Portland State University. She holds doctoral degree in Music Education from Boston University, MA in Music from Portland State University, and MA and BA in Musicology from the University of Arts, Faculty of Music, Belgrade, Serbia. She presented at international and national conferences and published on topics of music history pedagogy, e-Learning, and composer Petar Bergamo.

Jere T. Humphreys, Professor of Music at Arizona State University, is a music scholar who applies historical, quantitative, philosophical, and sociological research methods to music education and arts business. He was a Fulbright Senior Scholar in Macedonia and Fulbright Senior Specialist in Egypt and Turkey. His career includes lecturing, consulting, and presenting in 31 countries on 6 continents and across most of US states. 